\title{
FROGS (AMPHIBIA, ANURA) FROM THE EOCENE AND OLIGOCENE OF THE PHOSPHORITES DU QUERCY (FRANCE). AN OVERVIEW
}

\author{
JEAN-CLAUDE RAGE \\ Sorbonne Universités, CR2P CNRS-MNHN-UPMC Paris 6, Département Histoire de la Terre, Muséum National d'Histoire Naturelle, CP 38,57 rue \\ Cuvier, 75005 Paris, France; e-mail: jcrage@mnhn.fr.
}

Rage, J.-C. (2016): Frogs (Amphibia, Anura) from the Eocene and Oligocene of the Phosphorites du Quercy (France). An overview. - Fossil Imprint, 72(1-2): 53-66, Praha. ISSN 2533-4050 (print), ISSN 2533-4069 (on-line).

\begin{abstract}
Anuran assemblages from the Eocene and Oligocene of the Phosphorites du Quercy (southwestern France) are documented by a modest number of isolated bones, incomplete skulls, and some 'mummies'. However, at the family level, the diversity is not significantly lower than in coeval frog assemblages from other regions. By contrast, a larger number of amniote specimens and taxa are known from the Phosphorites. The sparse anuran record within the Phosphorites most likely results from the karstic environment in which the fossiliferous sites formed. Such an environment is not favorable for animals dependent on water and moisture. Upper middle and upper Eocene localities in the Phosphorites produced Alytidae, Pelobatidae, Pelodytidae and ranoids. The presence of bufonids or microhylids, and rhacophorids cannot be definitely rejected, and potentially distinctive, but unidentifiable taxa also may be present. The occurrence of Pelodytidae in the Eocene of Europe is confirmed by diagnostic bones from the Phosphorites. In Oligocene localities in the Phosphorites, anurans are even less diverse, with only Alytidae, Pelobatidae and ranoids having been recovered. Reduction in the number of individuals and diversity of anurans during the Oligocene is likely a consequence of both the extinction event (Grande Coupure) that took place at the Eocene-Oligocene boundary and increasing cooling and aridity during the Oligocene.
\end{abstract}

Key words: Amphibia, Anura, Cenozoic, Eocene, Oligocene, France, Phosphorites du Quercy

Received: January 4, 2016 | Accepted: March 3, 2016 | Issued: August 15, 2016

\section{Introduction}

The Phosphorites du Quercy (hereafter referred to as 'the Phosphorites') include numerous fossiliferous sites located on limestone plateaus in the Quercy region, southwestern France (Text-fig. 1). These sites are karstic fissures in-filled by phosphatic sediments, hence the name 'Phosphorites'. More than 100 fossiliferous localities are known (Legendre et al. 1997, Pélissié and Sigé 2006). The localities produced rich faunas of terrestrial vertebrates that range from the early Eocene (standard level MP 8+9; Astruc et al. 2003) to the early Miocene (MN 3; Sigé et al. 1991, Maridet et al. 2013: supplemental), but almost all localities range from the late middle Eocene (MP 16) to the late, but not latest Oligocene (MP 28) (for details about standard levels, see Schmidt-Kittler 1987).

Collections from the Phosphorites were gathered during two distinct phases: during the second half of the $19^{\text {th }}$ century and from the late 1960s onward. The fossils collected during the first phase make up the 'old collections'; the precise provenances and geological ages of these specimens are unknown. By contrast, the provenances and geological ages of fossils collected during the second phase are known (Rage 2006).

The first report on anurans from the Phosphorites is likely that of Filhol (1873), who briefly described, but did not name, 'mummies' that subsequently became part of the type series of Rana plicata FILHOL, 1876, a taxon that was recently referred to the synonymy of Thaumastosaurus gezei RAGE et ROČEK, 2007 (see below). Other early reports include: Filhol (1876), who erected the taxa Bufo serratus FILHOL, 1876 and Rana plicata (but see Martín et al. 2012); Filhol (1877), who illustrated various amphibian 'mummies'; and de Stefano (1903a), who described the anuran Thaumastosaurus bottii DE STEFANO, 1903, erroneously interpreted by him as a lizard.

As stated above, the fossiliferous sites formed in a karstic area. Such an environment is not favorable for animals highly dependent on water and moisture. Consequently, whereas fossils and taxa of amniotes are numerous and diverse (e.g, Legendre et al. 1997, Pélissié and Sigé 2006), fishes and amphibians are rare (Rage 2006). Amphibians from the Phosphorites have rarely been investigated. In addition, while urodeles from the old collections were studied by de Stefano (1903b), the anurans have never been the subject of a general survey. The present article is an attempt to address this shortcoming.

The material is housed in the collections of the Institut des Sciences de l'Evolution, Université de Montpellier (UM) and in those of the Muséum national d'Histoire naturelle, Paris (MNHN). 


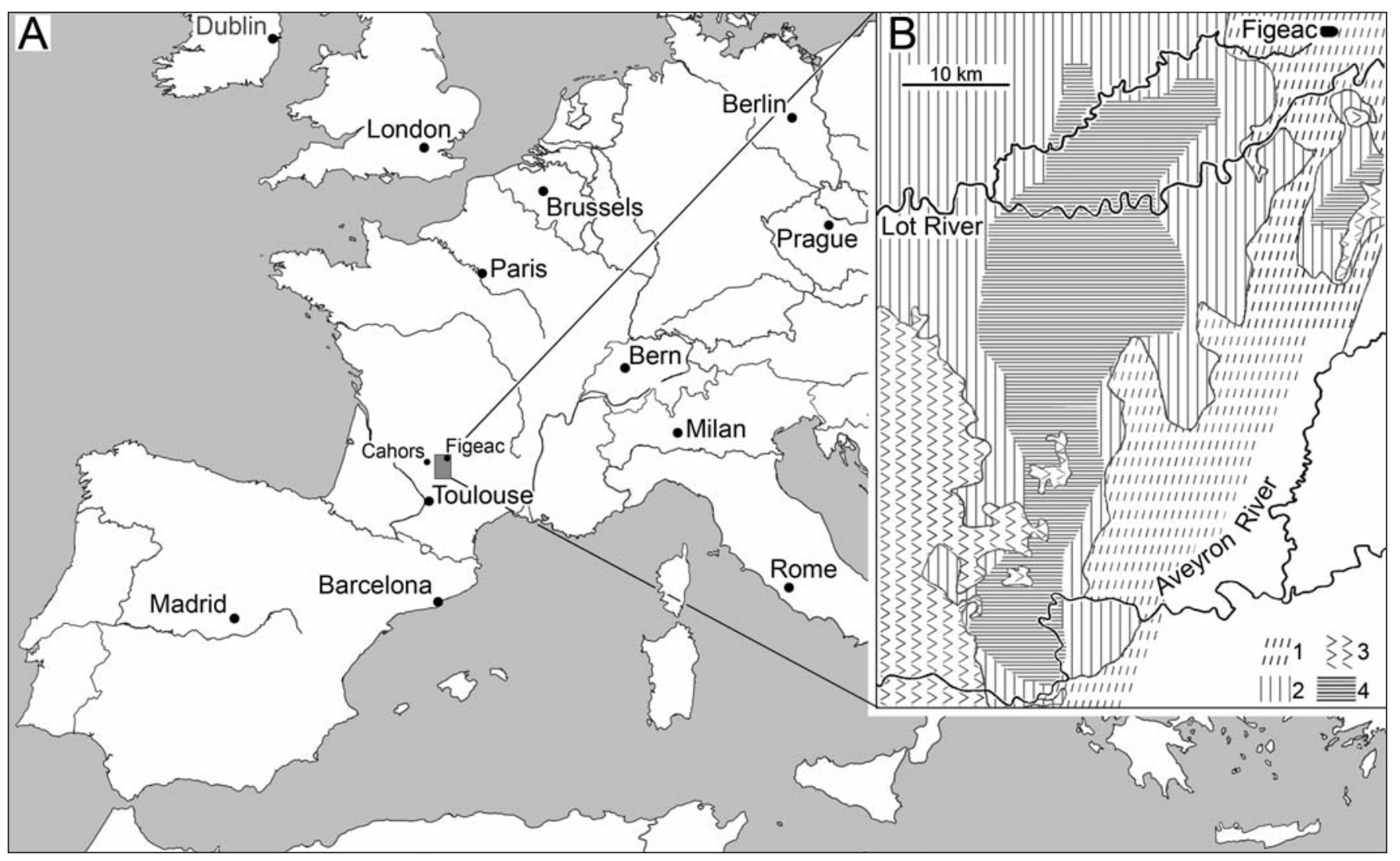

Text-fig. 1. Map showing the position of the Phosphorites du Quercy in Europe (A), and their geographic extent on a local map (B). 1: Lower Jurassic; 2: Middle and Upper Jurassic; 3: Cenozoic; 4: geographic extent of the Phosphorites.

\section{Systematic Paleontology}

\section{Alytidae Fitzinger, 1843 Discoglossus group}

(Text-fig. 2: 1-6)

The Alytidae are currently present in Europe, northwesternmost Africa and the western Middle East. They include three living genera, Alytes WAGLER, 1830, Discoglossus ОтTн, 1837 and Latonia VON MEYer, 1843 (Biton et al. 2013). These frogs, with two other living genera (Bombina OKEN, 1816 and Barbourula TAYLOR et NOBLE, 1924) have been traditionally referred to as Discoglossidae GüNTHER, 1858. However, Frost et al. (2006) split the Discoglossidae into two families, the Alytidae and the Bombinatoridae GrAY, 1825. The name Discoglossidae disappeared and, in Frost et al.'s classification, its equivalent is Costata LATASTE, 1879. However, the name Discoglossidae is still widely used, mainly in paleontology (e.g., Roček et al. 2010, Szentesi and Venczel 2012, Gardner and DeMar 2013, Venczel and Hír 2013).

The Alytidae first occur in the Middle Jurassic (Bathonian) of England (Evans et al. 1990). They range among the earliest known anurans (Triassic forms being salientians, not anurans) and, from the Middle Jurassic onwards, they have been present in Europe. Most fossils belong to the 'Discoglossus group', more specifically they are related to the Discoglossus-Latonia assemblage (Roček 1994).

In the Phosphorites, Alytidae are rare, especially in the Eocene. In his unpublished thesis, Duffaud (2000) reported a possible scapula from Sainte-Néboule (MP 18), but the specimen was neither described nor figured and now is missing from the collections. For the time being, a single fragment of urostyle from Rosières 1 (MP 19) demonstrates that alytids were present in the Phosphorites before the Oligocene (Text-fig. 2: 1). However, outside of the Phosphorites, alytids were more frequent, although never numerous, in the European Eocene (Rage and Ford 1980, Milner 1986).

In the Oligocene, alytids occur from MP 21 to MP 25 and in MP 28. Alytids from the Oligocene were all referred to as Discoglossus cf. giganteus by de Bonis et al. (1973: table 2-5). D. giganteus WeTtSTEIN-WESTERHEIMB, 1955 is now included in the genus Latonia, as L. gigantea (Roček 1994, Rage and Hossini 2000). Before Roček's revision of Latonia (Roček 1994), various alytids from the Cainozoic were erroneously assigned to $D$. giganteus. However, there is likely more than one alytid taxon in the Oligocene of the Phosphorites. The few alytids from the early Oligocene (MP 21 and MP 22) appear to be about twice the size of the younger specimens (Text-fig. 2: 2,3) and, based on urostyles, their size is similar to that of the only specimen known from the Eocene. This difference in size may correspond to a taxonomic distinction, but this cannot be demonstrated on the basis of the available material. In addition, in MP 23, large and smaller alytids coexisted. Duffaud (2000) suggested that Latonia vertaizoni FRIANT, 1944 might be present in the Oligocene of the Phosphorites. The latter taxon is known by a single specimen from Vertaizon, a locality relatively close to the Quercy and whose age is regarded as late Oligocene, although an early Miocene age cannot be rejected (Gaudant 1993). Unfortunately, comparisons are almost impossible because the holotype 


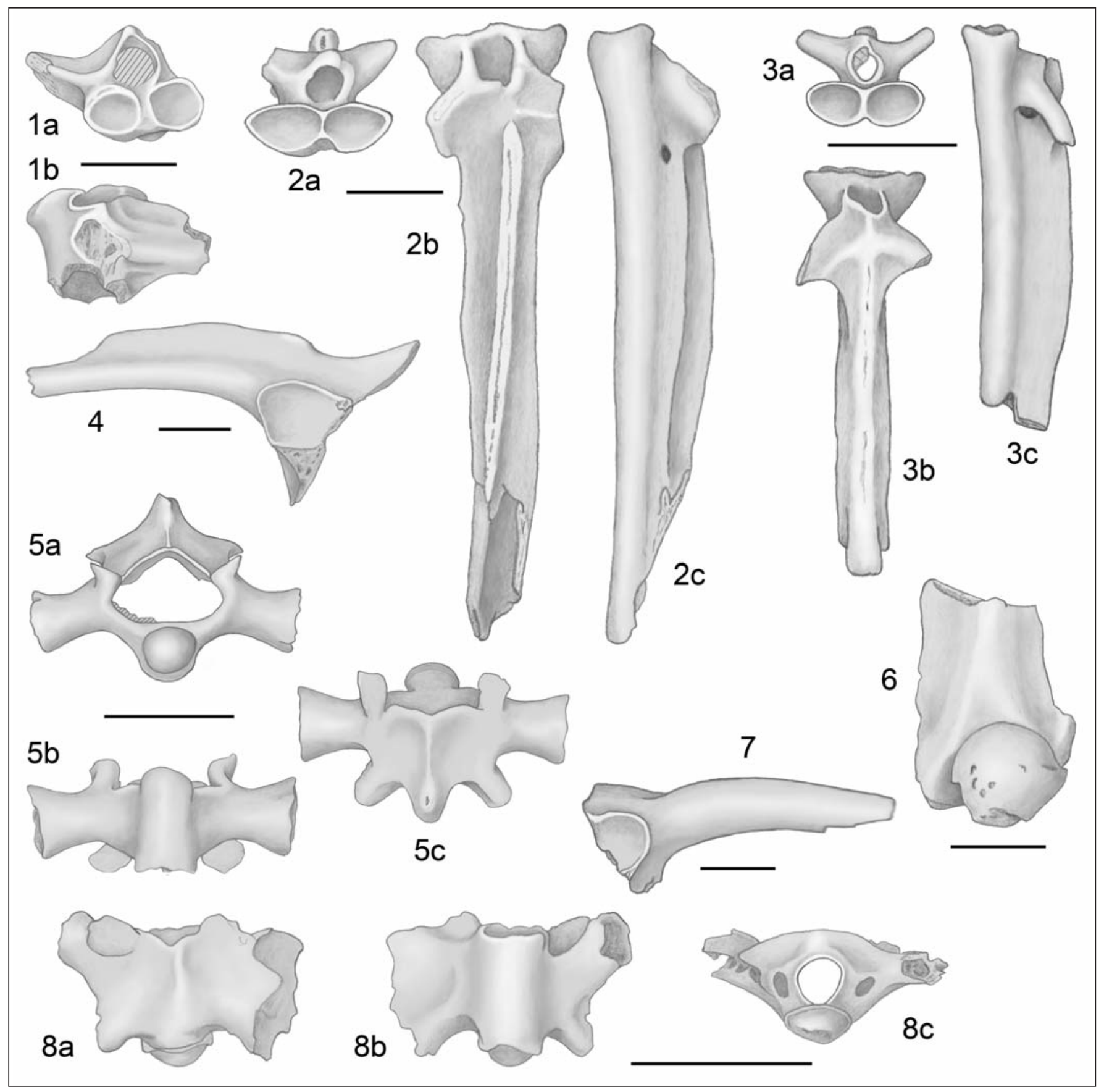

Text-fig. 2. Alytidae and Pelobatidae from the Phosphorites du Quercy. 1: Alytid indeterminate, urostyle UM-ROS1-601, from the late Eocene of Rosières 1 (MP 19), in anterior (a) and dorsal (b) views. 2: Alytid indeterminate, urostyle UM-ABL1-1901, from the earliest Oligocene of Aubrelong 1 (MP 21), in anterior (a), dorsal (b), and left lateral (c) views. 3: Alytid indeterminate, urostyle UM-BEL 1513, from the middle Oligocene of Belgarric (MP 25), in anterior (a), dorsal (b), and left lateral (c) views. 4: Alytid indeterminate, left ilium UM-GAO3-01, from the early/middle Oligocene of Gardiol 3 (MP 23), in lateral view. 5: Alytid indeterminate, presacral vertebra UM-BEL 1512, from the middle Oligocene of Belgarric (MP 25), in anterior (a), ventral (b), and dorsal (c) views. 6: Alytid indeterminate, left humerus UM-BEL 1514, from the middle Oligocene of Belgarric (MP 25), in ventral view. 7: Pelobatid indeterminate, right ilium UM-RAV 3500, from the earliest Oligocene of Ravet (MP 21), in lateral view. 8: Pelobatid indeterminate, sacral vertebra UM-ECC 2547, from the late Eocene of Escamps (MP 19), in dorsal (a), ventral (b), and posterior (c) views. Each scale bar = 3 mm.

of $L$. vertaizoni is an articulated skeleton whose bones are poorly preserved (Roček 1994: fig. 19).

The Alytidae from the Phosphorites cannot be identified to genus level. However, various features observable on the available bones demonstrate that these alytids belong to the 'Discoglossus group' (presence of a dorsal crest on the ilium, tuber superius formed by a thickening of the posterior part of the latter crest, vertebral centrum cylindrical, neural spine projecting posteriorly beyond the level of the postzygapophyses, distal part of the humerus relatively expanded transversely; Text-fig. 2: 4-6).

\section{Pelobatidae Bonaparte, 1850}

(Text-fig. 2: 7, 8)

The Pelobatidae, as defined by Roček et al. (2014), include only one extant genus (Pelobates WAGLER, 1830) and 
the extinct Eopelobates PARKER, 1929. Extant pelobatids inhabit Europe, western Asia and northwesternmost Africa. The earliest known pelobatids were recovered from the earliest Eocene (MP 7) of Europe (Rage and Roček 2003, Rage 2012). Older pelobatids were reported, but they are better referred to as pelobatids s.l., an assemblage that encompasses the Asian Megophryidae BONAPARTE, 1850 and North American Scaphiopodidae CoPE, 1865 in addition to Pelobatidae s.s.; these three groups were formerly regarded as subfamilies of the Pelobatidae. Pelobatids from the early Eocene of Europe remain unidentified below family level. Although Eopelobates sp. was reported from the early Eocene (Ypresian) of Europe (Sanchiz 1998) and Asia (Folie et al. 2013), the earliest confirmed representatives of the genus are E. wagneri (WeITZEL, 1938) from the early middle Eocene (MP 11) of Messel, Germany (Wuttke 2012), and the approximately coeval E. deani RoČEK, WUTTKE, GARDNER et BHULLAR, 2014 from Wyoming, the USA (Roček et al. 2014). According to Duffaud (2000) and Roček et al. (2014), the earliest representatives of Pelobates are disarticulated remains from the early Oligocene (MP 22) of Mas-de-Got, a locality of the Phosphorites.

Pelobatidae were first reported from the Phosphorites by Hoffstetter (1945), but this identification was erroneous (see below 'Thaumastosaurus'). However, the presence of pelobatids in the Phosphorites subsequently was confirmed (e.g., de Bonis et al. 1973, Crochet et al. 1981, Duffaud 2000, Rage 2006), but identification of these fossils below family level is difficult.

The distinction between Pelobates and Eopelobates is not easy. It is mainly based on skull bones (Roček et al. 2014) and most of the specimens from the Phosphorites do not appear to be adequate for distinguishing between these two genera. Isolated bones from the Phosphorites are generally post-cranial elements, whereas the available skull bones are often incomplete and may be confused with those of the ranoid Thaumastosaurus DE STEFANO, 1903, which bears a pelobatid-like ornamentation. The pelobatid material from the Phosphorites needs to be revised. The most frequent bones are ilia and vertebrae. Within pelobatids, the morphology of the ilia is quite homogenous (Text-fig. 2: 7) and it does not permit easy identification. Posterior presacral vertebrae might be useful because spinal foramina are sometimes present (Rage and Augé 2015, Blain et al. 2016), which is an exceedingly rare character in anurans; however, the taxonomic significance of this feature, if any, remains unknown. Sacral vertebrae are generally found to be a useful tool for identification, but they are rare in localities and usually poorly preserved (Text-fig. 2: 8).

Duffaud (2000) mentioned Eopelobates aff. bayeri from the late Eocene (MP 19) and the earliest Oligocene (MP 21) of the Phosphorites. Rage (2006) reported those fossils as Eopelobates aff. anthracinus because Sanchiz (1998) regarded E. bayeri ŠPINAR, 1952 as a junior synonym of E. anthracinus PARKER, 1929; however, this synonymy was not recognized by Roček et al. (2014). However, the available material does not permit such precise identification. At present, it is only possible to state that Pelobatidae are present in the Phosphorites from MP 16, late middle Eocene (Rage 1988) to MP 23, early/ middle Oligocene (Duffaud 2000). In younger levels of the Phosphorites, anurans become rare and, despite the report of a pelobatid as cf. Pelobates from the late Oligocene (MP 28)
(Crochet 1972), the presence of representatives of the family after MP 23 has not been confirmed.

\section{Pelodytidae Bonaparte, 1850}

Pelodytidae are a small family that includes a single extant genus, Pelodytes Bonaparte, 1838. The genus inhabits disjunct areas, i.e. southwestern Europe and the Caucasus region. An extinct species, $P$. arevacus SANCHIZ, 1978, was described from the Miocene of Spain (Sanchiz 1978, 1998). The family is known also from North America where it is represented by Miopelodytes gilmorei TAYLOR, 1941 from the middle Miocene of Nevada, U.S.A. (Taylor 1941, Sanchiz 1998). Moreover, a stem pelodytid (Aerugoamnis paulus HENRICI, BÁEZ et GRANDE, 2013) was described from the early Eocene of Wyoming, the U.S.A. (Henrici et al. 2013).

Pelodytids were reported from the Phosphorites, but no species was described. All specimens suggest a taxon similar to Pelodytes, if not Pelodytes itself. They were referred to as cf. Pelodytes (Crochet et al. 1981, Rage 1984a, 1988, 2006, Duffaud 2000). In the Phosphorites, cf. Pelodytes was recovered only from Eocene localities. The identification of this taxon was more or less questioned by Henrici et al. (2013), therefore description of the specimens, including a recently recovered tibiale-fibulare, is warranted.

\section{cf. Pelodytes Bonaparte, 1838}

(Text-fig. 3)

In the Phosphorites, the taxon is represented by vertebrae, ilia, humeri and one fused tibiale-fibulare (Text-fig. 3). Vertebrae show a combination of features that is characteristic of Pelodytes (Text-fig. 3: 1, 2). They are proceolous, lightly built and the centrum, cotyle and condyle all are markedly depressed dorsoventrally. In ventral aspect, the ventral parts of the lateral walls typically extend laterally on either side of the centrum. The neural arch is of the imbricate type, i.e. it is anteroposteriorly long. The posterior projection of the neural spine is relatively weak. In posterior presacral vertebrae, the bases of the transverse processes originate approximately below the prezygapophyses and they project markedly anterolaterally. One incomplete sacral vertebra may belong to this taxon; however, it is regarded as belonging to an indeterminate anuran because it bears postzygapophyses (see below: 'Problematic taxa').

The ilia lack both a dorsal crest and a tuber superius, as do those of pelobatids (Text-fig. 3: 4). However, their shaft is markedly curved in lateral view and the dorsal border of their pars ascendens (ischiatic process) is slightly curved dorsally, which distinguishes them from pelobatid ilia.

Humeri are very similar to those of Pelodytes (Text-fig. 3: 3). They have a slender and almost straight diaphysis that bears ventral and paraventral crests. The articular ball is well defined, comparatively small and scarcely shifted laterally. The distal part of the lateral border of the bone (crista lateralis not taken into account), close to the articular ball, forms a gentle curve that is slightly convex laterally; this part of the humerus is generally concave in anurans.

A fused tibiale-fibulare (Text-fig. 3: 5) belonging to a pelodytid was recovered among the specimens of anurans from the late Eocene of Malpérié (MP 17) by Duffaud (2000). In almost all anurans, the tibiale and fibulare are elongate and fused only at their extremities. However, in pelodytids, 


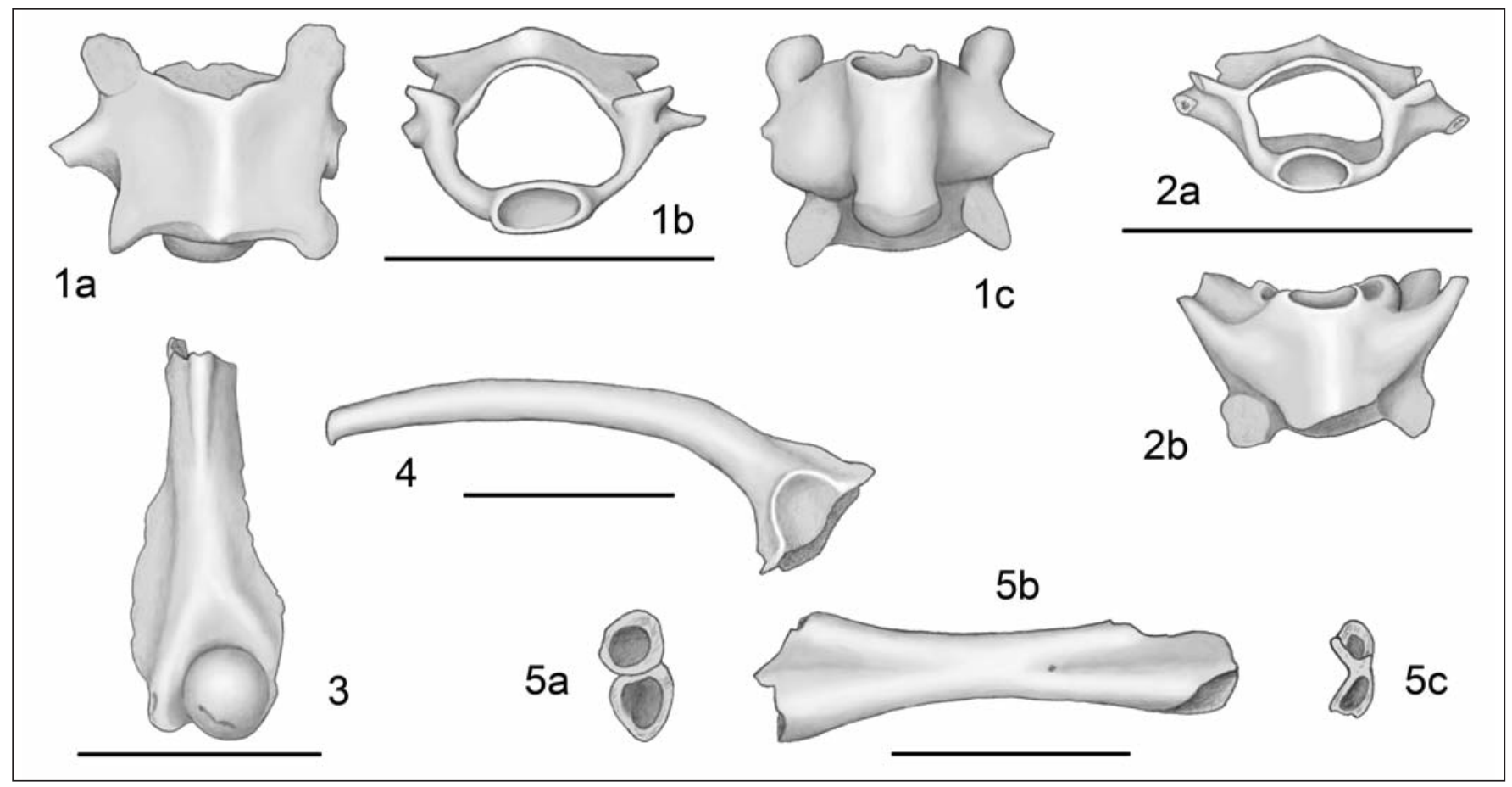

Text-fig. 3. Pelodytidae (cf. Pelodytes) from the Phosphorites du Quercy. 1: presacral vertebra UM-MAL 617, from the late Eocene of Malpérié (MP 17), in dorsal (a), anterior (b), and ventral (c) views. 2: posterior presacral vertebra UM-SNB 2406, from the late Eocene of Sainte-Néboule (MP 18), in anterior (a) and ventral (b) views. 3: right humerus UM-ECA 2556, from the late Eocene of Escamps (MP 19), in ventral view. 4: left ilium UM-ECA 2534, from the late Eocene of Escamps (MP 19), in lateral view. 5: right tibiale-fibulare UM-MAL 616, from the late Eocene (MP 17) of Malpérié (proximal section (a); dorsal view (b); and distal section (c)). Each scale bar = $3 \mathrm{~mm}$.

centrolenids (an extant Central and South American family) and Tephrodytes HENRICI, 1994 (but not in rhinophrynids, contra Trueb 1973), they are fused throughout their length and form a single element. This element thus resembles the anuran tibiofibula; however, it is shorter and its extremities are more expanded. In addition the proximal ends of the tibiale and fibulare are approximately circular, whereas the distal extremities are clearly flattened. Traces of the fusion remain as grooves, except in the central portion of the bone. This tibiale-fibulare from Malpérié clearly displays this morphology, which is characteristic of Pelodytes (Sanchiz 1978). It differs from that of Miopelodytes TAYLOR, 1941 in being more slender; more specifically, its extremities are less expanded. The fused tibiale-fibulare of centrolenids is markedly more elongate and slender (Guayasamin et al. 2009). The fused tibiale-fibulare from Malpérié cannot be distinguished from the tibiale-fibulare of extant Pelodytes and it also closely resembles that of Tephrodytes (Oligocene-Miocene transition of the USA; Henrici 1994). Tephrodytes was first referred to the Pelodytidae (Henrici 1994) but Henrici et al. (2013) placed it among pelobatids s.l. However, the morphology of various bones suggests that Tephrodytes may be more closely related to the Pelodytidae.

In conclusion, the specimens from the Phosphorites allocated to Pelodytidae are quite similar to those of extant Pelodytes. Henrici et al. (2013: 304) noted that reliable referral of the remains from the Eocene of Europe to pelodytids (as cf. Pelodytes) would require finding of a fused tibiale-fibulare in the same localities. The recovery of such a tibiale-fibulare confirms that a fossil taxon closely related to Pelodytes, if not Pelodytes, is present in the late middle and late Eocene (from
MP 16 to MP 19) of western Europe, more specifically in the Phosphorites.

\section{Ranoidea RAFINESQUE, 1814}

Ranoids (i.e. Ranoides of Frost et al. 2006) make up a huge, monophyletic clade within the Neobatrachia. This is a widely distributed group absent only from South America and, obviously, Antarctica. This clade and its included families have had a complex taxonomic history that cannot be reported here (Frost et al. 2006; see also Amphibian Species of the World: an Online Reference, Version 6.0, edited by D. R. Frost (accessed 10 February 2016), http://research.amnh.org/herpetology/amphibia/index.html).

The earliest ranoid is represented by a few isolated bones from the Cenomanian of Sudan (Báez and Werner 1996); unfortunately, these specimens remain undescribed. Stratigraphically, the next possible ranoid occurs in the ConiacianSantonian of In Beceten, Niger (de Broin et al. 1974, Rage $1984 b$, in progress). Ranoids may also be present in the Paleocene of Cernay, France (Estes et al. 1967, Rage 1984b). Ranoids become more frequent, although still not numerous, in the Eocene and they are present in the Phosphorites. Two ranoid groups from the Phosphorites are considered separately below: the genus Thaumastosaurus and unidentified taxa.

\section{Family indeterminate}

\section{Thaumastosaurus de STEFANO, 1903}

Among amphibians from the Phosphorites, the genus Thaumastosaurus has been the most studied taxon and its 
history is complicated. Thaumastosaurus was erected by de Stefano (1903a) for his species T. bottii, which is the type species of the genus. De Stefano regarded T. bottii as a lizard and he described it under the heading 'genus incertae sedis'. The taxon was based on a single specimen from the Phosphorites, i.e. a posterior braincase plus incomplete frontoparietals and otic capsules. The specimen was subsequently lost and de Stefano was most likely the only paleontologist who studied it. Fortunately, the specimen was illustrated (de Stefano 1903a: pl. IX, figs 11 and 15) and its characteristics clearly appear in the figures. The specimen came from the old collections, therefore neither its precise provenance nor its age are known.

Nopcsa (1908) regarded the name Thaumastosaurus DE STEFANO, 1903 as a homonym of Thaumattosaurus VON Meyer, 1841 (in fact, Nopcsa misspelled the name of Thaumatosaurus VON MEYER, 1841, a plesiosaur today synonymized with Rhomaleosaurus SEELEY, 1874). Nopcsa (1908) coined the replacement name Enigmatosaurus NoPCSA, 1908, but he still regarded it as a lizard. Piveteau (1927) described a relatively complete anuran skull coming also from the old collections. He associated this skull (now MNHN.F.QU17736) with the dentary of a gekkonid lizard from the old collections and identified the two specimens as Amphignathodon sp. (i.e., an extant genus). The latter genus today is referred to the synonymy of Gastrotheca FITZINGER, 1843, a South American hemiphractid frog genus that includes the only species of anuran bearing teeth on its lower jaw. On the basis of the original figures, Hoffstetter (1945) showed that the fossil described by de Stefano was an anuran, not a lizard, and he referred to it as Enigmatosaurus bottii (DE STEFANO, 1903). In addition, he assigned to this species the skull MNHN.F.QU17736 described by Piveteau (1927). Based on the ornamentation of the dermal bones, Hoffstetter suggested that this anuran may be a Pelobatidae. Subsequently, the skull MNHN.F.QU17736 was temporarily lost.

In the 1970s, new excavations in the Phosphorites yielded several specimens belonging to Thaumastosaurus. Surprisingly, as with de Stefano's lost specimen, they were all represented by the posterior part of a braincase plus otic capsules and fused posterior parts of the frontoparietals. Fossilization of this part of the skull of Thaumastosaurus, which is marked by hyperossification, clearly is favored. Based on this new material, Crochet et al. (1981: tab. 2-1) reported the taxon (as Enigmatosaurus bottii) from six (plus perhaps another two) localities of late Eocene age in the Phosphorites. The species then was regarded as a possible Leptodactylidae, an assignment that was not discussed in the article.

The tentative referral to the 'leptodactylids', an assemblage now regarded paraphyletic, was briefly discussed by Rage (1981). The assignment was based on the similarity of the skull with that of 'ceratophryines' (then included in the 'leptodactylids') and on the presence, in the same localities as the skull bones, of fragments of bony plates bearing a pustular ornamentation similar to that of the dorsal shield of 'ceratophryines'. Thaumastosaurus was therefore regarded as an anuran with South American affinities ('ceratophryines' being restricted to South America). Thereafter, such biogeographical affinities were supported by Roček and Lamaud (1995), Rage and Roček (2007), Evans et al. (2008, 2014) and Agnolin (2012). Roček and Lamaud (1995) provided the first detailed description of Thaumastosaurus bottii, based on various skull bones from La Bouffie, a late Eocene (MP 17) locality in the Phosphorites. They also showed that the one-letter difference between Thaumastosaurus DE STEFANO, 1903 and Thaumatosaurus VON MEYER, 1841 (or the misspelled Thaumattosaurus) prevents homonymy, and that the name Enigmatosaurus NOPCSA, 1908 is a junior synonym of Thaumastosaurus DE STEFANO, 1903. By the early 2000s, the skull MNHN. F.QU17736, formerly described by Piveteau (1927) and temporarily lost, was found in the collections. Rage and Roček (2007) described it, showed that it belonged to Thaumastosaurus and demonstrated that it represents a second species, $T$. gezei. At that time, the latter species was known only by two specimens from the old collections: the skull (i.e. the holotype) and a squamosal.

Laloy et al. (2013), using tomography, studied the so-called 'mummy' of Rana plicata FILHOL, 1876 (i.e., Rana cadurcorum MARTín, Alonso-ZARAZAGA et SANCHIZ, 2012). They also scanned the 'mummy' of a forelimb, which might have broken off the main 'mummy' according to Filhol (1877). It was not possible to confirm whether the forelimb belongs to the 'mummy'. The tomographic study revealed that the skull of the 'mummy' is identical to that of Thaumastosaurus gezei and, on that basis, the 'mummy' was referred to the latter species. Thanks to a large part of the post-cranial skeleton being preserved in the 'mummy', much of that region is now reliably known for T. gezei (e.g., Text-fig. 4: 1, 2). A recent phylogenetic analysis including post-cranial characters demonstrated that Thaumastosaurus does not belong to a South American clade, but that it belongs instead to the ranoid assemblage; more specifically, it appears to be related to pyxicephalids, an endemic African group (Laloy et al. 2013). This is a good example of how an over-reliance on cranial features related to hyperossification, which can be convergent among unrelated groups of anurans, may adversely affect phylogenetic analyses (Báez and Gómez 2014, Evans et al. 2014).

New knowledge about part of the post-cranial skeleton now can be used to identify isolated post-cranial bones in the material collected during recent excavations. Unfortunately, post-cranial bones are known only in $T$. gezei, thus differences with post-cranial elements of $T$. bottii remain unknown. Therefore, in this paper, all disarticulated post-cranial bones from the Phosphorites similar to those of T. gezei are referred to as Thaumastosaurus sp. Such is the case, for instance, of scapulae (characterized by a marked dorsoventral elongation; Text-fig. 4: 3) and one humerus (characterized by an articular ball that rather weakly protrudes and is slightly shifted laterally, and by a moderately developed lateral epicondyle; Text-fig. 4: 4). This is also the case for various cranial bones that cannot be allocated at species level (Rage and Roček 2007).

It is worth noting that, although a part of the ilium is preserved in the 'mummy' of $T$. gezei, it is not possible to rank this bone among the post-cranial elements of Thaumastosaurus whose morphology is known. Ilia are among the most frequently recovered anuran bones and among the most useful ones for purposes of identification (Roček et al. 2013, Gómez and Turazzini 2016). Unfortunately, in T. gezei only the anterior extremity of one ilium is known, and it shows only that the shaft bears a medially inclined dorsal crest (Laloy et al. 2013). Unfortunately, this feature is not sufficient for identification within ranoids; consequently, no 
isolated ilium from the Phosphorites or elsewhere may be confidently assigned to Thaumastosaurus.

For the time being, in the Phosphorites we must distinguish between Thaumastosaurus bottii (the type species), T. gezei and Thaumastosaurus sp. Outside of the Phosphorites, two species were assigned to Thaumastosaurus: T. wardi and T. sulcatus, described by Holman and Harrison (2002) and Holman and Harrison (2003), respectively. Both non-Phosphorites species were recovered from the late Eocene (MP 17) of southern England.

\section{Thaumastosaurus bottii DE STEFANo, 1903}

T. bottii is reliably known from a single locality, La Bouffie, of late Eocene (MP 17) age. It was redescribed by Roček and Lamaud (1995) and it is known only by skull bones. It should be noted that in Rage's (2006) treatment, all bones belonging to Thaumastosaurus were assigned to $T$. bottii, because only that species was known at that time; this resulted in a likely erroneous stratigraphic range being reported for this species, extending from MP 16 to MP 19 and perhaps MP 20 (Rage 2006: 166, tabl. 3).

\section{Thaumastosaurus gezei RAGE et RoČEK, 2007}

\section{(Text-fig. 4: 1,2)}

T. gezei is known by three or perhaps five specimens from the old collections of the Phosphorites. These specimens are the holotype skull (MNHN.F.QU17376), a squamosal (MNHN.F.QU17748) (Rage and Roček 2007), the 'mummy' (MNHN.F.QU17279), and perhaps a forelimb (MNHN.F.QU17280) (Laloy et al. 2013) and another, incomplete 'mummy' (MNHN unnumbered, figs 406, 407, 411 in Filhol 1877) whose external morphology resembles that of MNHN.F.QU17279. Because the specimens are all from the old collections, the precise geological age of the species remains unknown. This age may range from the late middle Eocene (MP 16) to the latest Eocene (MP 19, perhaps MP 20), i.e. the maximum known range of Thaumastosaurus $\mathrm{sp}$.

\section{Thaumastosaurus sp.}

$$
\text { (Text-fig. 4: 3, 4) }
$$

Among specimens referable to Thaumastosaurus sp. are a humerus, a $8^{\text {th }}$ presacral and a sacral vertebrae that were all regarded as belonging to a large Ranidae RAFINESQUE, 1814 by Rage (1984b: fig. 2A, C, D). During the recent excavations, specimens referable to Thaumastosaurus sp. were recovered in localities ranging from MP 16 (localities of Le Bretou and Lavergne; late middle Eocene) to MP 19, perhaps MP 20 (latest Eocene); the youngest specimen is a fragment of maxilla from Tabarly (MP 20) that is tentatively assigned to the genus.

\section{Indeterminate ranoids}

\section{(Text-fig. 4: 5-9)}

Indeterminate ranoids from the Phosphorites include part of the 'Ranidae' reported by Rage (1984b). These 'Ranidae' are all represented by isolated bones. At that time, the concept of Ranidae was broader than it is today. The available bones closely resemble those of Recent European ranids and, therefore, they were assigned to the Ranidae (Rage 1984b). Sanchiz (1998) even suggested they probably represent the genus Rana Linnaeus, 1758 (Pelophylax Fitzinger, 1843 included in Sanchiz's concept of a broader Rana). However, it does not seem possible to demonstrate that these remains all belong to the Ranidae sensu stricto, as that family is now defined by Frost et al. (2006). In addition, as stated above, some bones (but not all) allocated to the 'large form' by Rage (1984b) actually belong to Thaumastosaurus sp.

In addition to Thaumastosaurus, at least three taxa of ranoids are present in the Phosphorites. This number of taxa is based on humeri. Indeed, three clearly distinct sizes are recognized. These specimens may be regarded as humeri of adult individuals (Text-fig. 4: 5-7), on the basis that for each morph the articular ball is entirely preserved and well shaped.

The small-sized ranoid (Text-fig. 4: 5) apparently occurs only in Eocene localities, from MP 16 (Lavergne) to MP 18 (Sainte-Néboule). In addition to humeri, at least one ilium, one scapula and some vertebrae may be referred to this small ranoid (Rage 1984b). The size and the morphology of the bones are homogenous, which suggests that this small form likely represents a single taxon.

The mid-sized ranoid is present in the Eocene (Textfig. 4:6) and Oligocene. Bones are rare and scattered in various localities. It is not possible to determine whether only one taxon is represented.

The size of the large form is similar to that of Thaumastosaurus. Humeri are distinguished from those of Thaumastosaurus by their more projecting articular ball, more developed lateral epicondyle and less slender diaphysis (Text-fig. 4: 7). A coracoid (Text-fig. 4: 9) from Escamps (MP 19) may be referred to this large taxon. It differs from that of Thaumastosaurus (Text-fig. 4: 2) in having a neck (corpus coracoidis, Špinar 1972) with more parallel borders and a more flaring pars epicoracoidalis. This large ranoid is reliably known from MP 16 to MP 19. It should be noted that Rage (1984b: fig. 2) reported a large ranoid from Lavergne (MP 16). However, as stated above, it is now possible to refer the humerus and vertebrae of this ranoid to Thaumastosaurus. The ilium of Thaumastosaurus being unknown, the ilium illustrated by Rage (1984b: fig. 2B) cannot be assigned within ranoids. Among ranoid bones from the Phosphorites figured by Rage (1984b), only the coracoid appears to belong to the large, indetermined ranoid.

As far as ranoids from the Eocene of the Phosphorites are concerned, the case of Rhacophoridae must be briefly addressed. This family was reported by Sanchiz (1998) from the Eocene of Escamps (MP 19). However, Sanchiz did not provide descriptions and he did not indicate on what bone(s) he based this identification. In view of the difficulty of identifying taxa within ranoids on the basis of isolated bones, neither the presence nor absence of rhacophorids may be confirmed. Today, the family occurs in sub-Saharan Africa and in southern and southeastern Asia. Fossils are known only from the Quaternary of Japan and perhaps from the Pliocene of eastern Europe (Sanchiz 1998).

Ranoids from the Oligocene of the Phosphorites are less frequent than in the Eocene. The few available bones do not permit reliable comparisons with specimens from the Eocene. Ranoid bones are unknown at Phosphorites from the basal Oligocene (MP 21) and apparently from MP 24 to MP 27. 


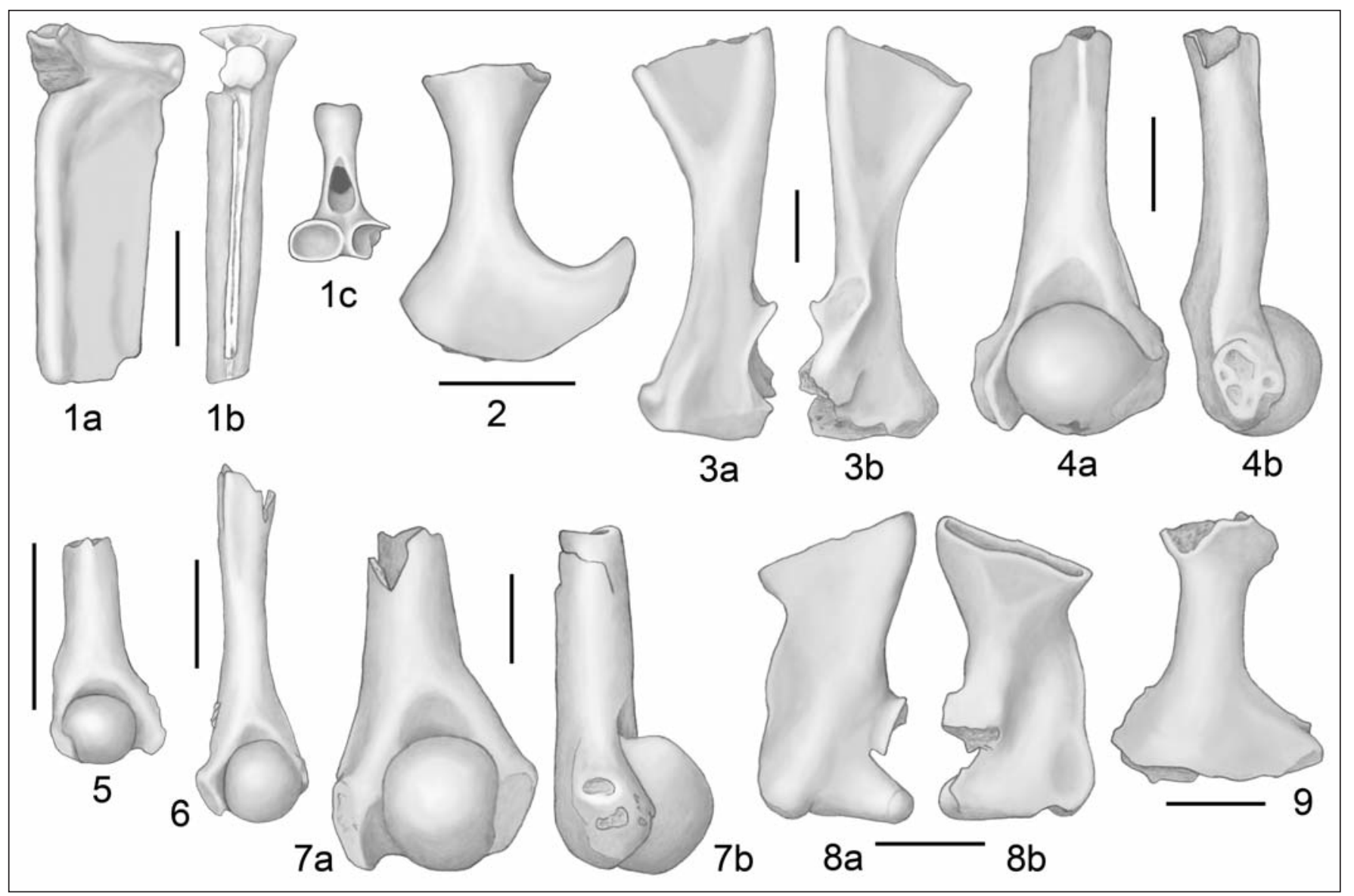

Text-fig. 4. Ranoids from the Phosphorites du Quercy. 1: Thaumastosaurus gezei, urostyle in left lateral (a), dorsal (b), and anterior (c) views. 2: T. gezei, left coracoid in medial view (the urostyle and coracoid are parts of the 'mummy' MNHN.F.QU17279). 3: Thaumastosaurus sp., left scapula UM-ECA 2537, from the late Eocene of Escamps (MP 19), in lateral (a) and medial (b) views. 4: Thaumastosaurus sp., left humerus UM-MAL 619, from the late Eocene of Malpérié (MP 17), in ventral (a) and medial (b) views. 5: Ranoid indeterminate, small-sized form, right humerus UM-LAV 1280, from the late Eocene of Lavergne (MP 16), in ventral view. 6: Ranoid indeterminate, mid-sized form, left humerus UM-ECA 2558, from the late Eocene of Escamps (MP 19), in ventral view. 7: Ranoid indeterminate, large sized form, left humerus UM-ECA 2557, from the late Eocene of Escamps (MP 19), in ventral (a) and medial (b) views. 8: Ranoid indeterminate, mid-sized form, left scapula UM-ECA 2560, from the late Eocene of Escamps (MP 19), in lateral (a) and medial (b) views. 9: Ranoid indeterminate, large-sized form, left coracoid UM-ECA 2559, from the late Eocene of Escamps (MP 19), in medial view. (1 and 2, redrawn from images segmented by F. Laloy in 2012). Each scale bar $=3 \mathrm{~mm}$.

A report from the late Oligocene of Pech-du-Fraysse (MP 28; Crochet 1972) is not confirmed. This scarcity of material likely reflects increasing aridity during the Oligocene.

\section{Problematic taxa}

\section{Bufonid-like or microhylid-like anurans}

$$
\text { (Text-fig. 5: 1,2) }
$$

The overall morphology of several mid-sized ilia from the Eocene is reminiscent of bufonids. The shaft lacks a dorsal crest and the tuber superius and pars ascendens are both of moderate size. The tuber superius is more or less pointed dorsally and it shows some morphological variations (Text-fig. 5: 1,2). The tuber is similar to that of various extant bufonids, for instance Epidalea calamita (LAURENTI, 1768) and species of the Bufotes viridis (LAURENTI, 1768) group (both genera were previously included in Bufo GARSAULT, 1764). However, the pars descendens is broad and its anterior border and the shaft feature an angle ('VSA', Gómez and Turazzini 2016) that is approximately a right angle; this is likely not consistent with bufonids.
Rare vertebrae from Eocene localities, show an overall morphology consistent with bufonids (Rage and VergnaudGrazzini 1978), but this morphology may also occur in other taxa. On the other hand, the anteroposterior extent of the pars descendens on ilia is reminiscent of Microhylidae (e.g., Nokariya 1983, Lehr and Trueb 2007, Gómez and Turazzini 2016, pers. obs.). Such a pars descendens may be the reason for Sanchiz (1998)'s report of Microhylidae from Escamps (MP 19) as 'undescribed material from the French Eocene'. It is true that the specimens are somewhat similar to ilia of various microhylids, but the Phosphorites have not produced other bones suggesting the presence of Microhylidae. The above mentioned ilia were recovered from MP 17 (locality of Malpérié) and MP 19 (Escamps). An ilium from Le Bretou (MP 16) most likely belongs to the same taxon (Rage 1988: fig. 5).

Microhylids inhabit the Americas, southern and southeastern Asia, south and east Africa and Australia. The family was reported from the Oligocene-Miocene of Australia (Tyler 1994), the Quaternary of North America (Sanchiz 1998) and the Holocene of Madagascar (MacPhee et al. 1985). 
Regarding bufonids, their current natural range extends over all continents except Australia and Antarctica. The fossil record of bufonids is richer by far than that of microhylids, but it remains poor and patchy before the Miocene. Eocene bufonids were reported only from Europe, but according to Roček and Rage (2000) those earlier reports are all erroneous. However, the locality of São José de Itaboraí (Brazil) yielded bufonids (Estes and Reig 1973). This locality was traditionally dated from the Paleocene, but it is now regarded as close to the Paleocene-Eocene transition (Oliveira and Goin 2011) or even of early Eocene age (Gelfo et al. 2009). Therefore, Eocene bufonids are perhaps known in South America. Oligocene bufonids are reliably known only from Bolivia (Báez and Nicoli 2004). Oligocene bufonids were also reported from Asia (Kazakhstan), but they were only listed and not described (Chkhikvadze 1985); this Asian report needs confirmation. Unquestionable bufonids are present from the early Miocene onwards in at least North America and Europe (Roček and Rage 2000). Given that the earliest currently accepted bufonid was recovered from the late Paleocene of Europe (Rage 2003), a long gap in the bufonid range extends from that age to the early Miocene in Europe. Apparently, the Phosphorites do not fill, or even reduce this gap.

To summarize, the presence of Bufonidae GRAY, 1825 and/or Microhylidae GÜNTHER, 1858 in the Phosphorites cannot be confirmed on the basis of the available material.

\section{The case of Bufo servatus FilHoL, 1877}

In a review of the frogs from the Phosphorites, it is impossible not to touch on the problem of Bufo servatus. Filhol (1876) first named it Bufo serratus, but subsequently he described it as Bufo servatus (Filhol 1877). Martín et al. (2012) considered the second, misspelled name as the valid one (which would mean that Bufo serratus is a nomen nudum). Bufo servatus is known by a single specimen that is a 'mummy' from an unknown locality of the Phosphorites, i.e. its precise geological age is indeterminate. Posterior to the eyes are elongate, protruding ridges regarded as parotid glands by Filhol, an interpretation that is likely erroneous. These presumed parotid glands were the main reason for assignment of this fossil to bufonids. According to Sanchiz (1998), this species is a 'nomen vanum'.

\section{An enigmatic frog in the late Eocene ?}

Rage and Vergnaud-Grazzini (1978) mentioned a high ratio of amphicoelous anuran vertebrae in the late Eocene (MP 18) of Sainte-Néboule. In anurans, the vertebrae are all amphicoelous in only a few extant and extinct basal groups. The presence of such groups is not revealed by other bones in the Phosphorites. Moreover, in diplasiocoelous anurans (i.e., ranoids in the Phosphorites), one of the nine vertebrae (the $8^{\text {th }}$ one) is amphicoelous, whereas the others are procoelous. At Sainte-Néboule, six vertebrae belonging to ranoids were recovered, of which four are amphicoelous. These amphicoelous vertebrae are large, therefore they belonged to fully grown individuals. Moreover, their neural arch is short and their transverse processes are directed transversely, which is consistent with ranoids. The ratio of amphicoelous vertebrae is high (2/3) whereas it should be

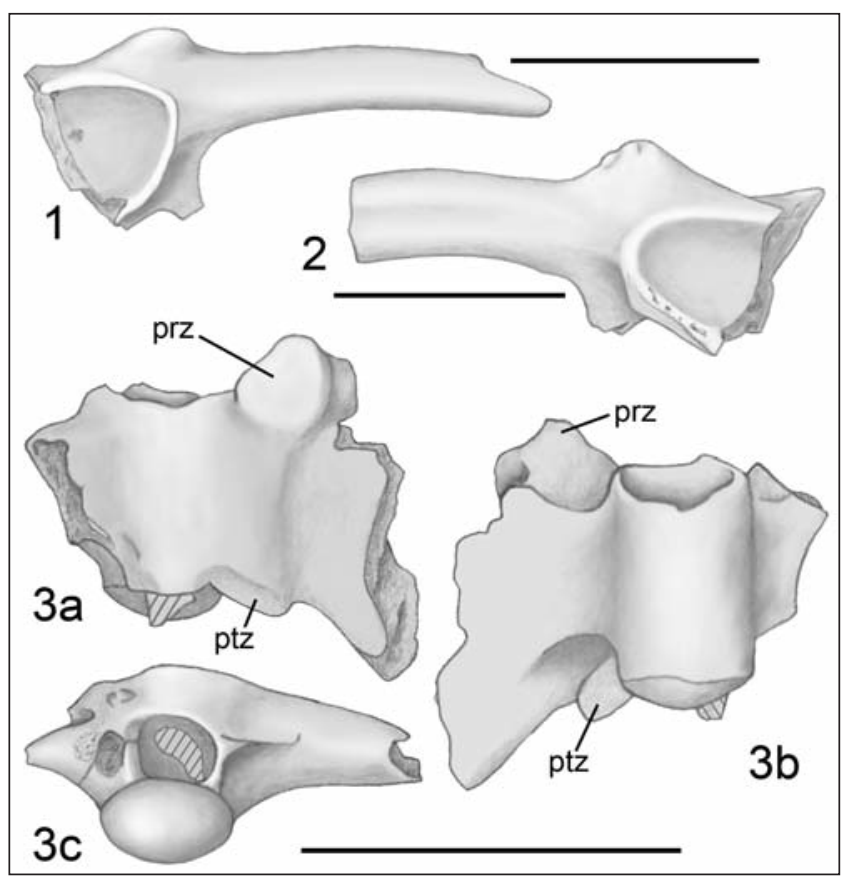

Text-fig. 5. Problematic anurans from the Phosphorites du Quercy. 1: Bufonid-like or microhylid-like anuran, right ilium UM-MAL 620, from the late Eocene of Malpérié (MP 17), in lateral view. 2: Bufonid-like or microhylid-like anuran, left ilium UM-MAL 621, from the late Eocene of Malpérié (MP 17), in lateral view. 3: Pelodytid or peculiar taxon ?, sacral vertebra UM-SNB 2405, from the late Eocene of Sainte-Néboule (MP 18), in dorsal (a), ventral (b), and posterior (c) views. (prz: prezygapophysis; ptz: postzygapophysis). Each scale bar $=3 \mathbf{m m}$.

markedly lower (theoretically: 1/9). Obviously, with the sample being so small, the ratio may not be significant; nevertheless, this situation remains somewhat puzzling. This problem is restricted to Sainte-Néboule.

\section{Pelodytidae or peculiar taxon ?}

\section{(Text-fig. 5: 3)}

A single sacral vertebra from the late Eocene (MP 18) of Sainte-Néboule is also problematic. It is incomplete, the sacral apophyses being damaged. However, the remaining part of the right apophysis shows that this apophysis was broadly expanded anteroposteriorly (more than in Miopelodytes) and, more specifically, that the posterior part was markedly extended. This feature and the overall morphology argue for referral to Pelodytidae. This vertebra bears a single posterior condyle for articulation with the urostyle. In Pelodytes, the posterior condyle is generally slightly subdivided by a weak vertical sulcus; therefore the condyle may appear as two condyles poorly distinguished from each other (Bailon 1999) but the degree of variation is high and, in some individuals, the condyle may be single (Sanchiz et al. 2002, pers. obs.). However, this vertebra is not identical to that of Pelodytes, the only extant genus in the family. It has thicker sacral apophyses, larger spinal foramina and, in addition to these differences, it shows a peculiar character: it bears a postzygapophysis on the right side (the symmetrical area is broken away) whereas, with the exception of rare 
Myobatrachidae (an extant family inhabiting Australasia), the sacral vertebra of anurans lacks postzygapophyses. However, postzygapophyses may appear as an irregular variation in non-myobatrachid frogs (e.g., Kovalenko and Kruzhkova 2013 , pers. obs). In that case, any postzygapophyses generally appear as pathological productions of irregular shape. In the specimen from Sainte-Néboule, the preserved postzygapophysis is well-shaped and well-positioned; it does not look like an abnormality.

It is worth considering however whether the specimen from Sainte-Néboule might not be a sacral vertebra. Individual anurans may develop a sacral apophysis on the vertebra that immediately precedes the sacral vertebra; even more rarely, two sacral apophyses may occur on the last presacral vertebra and are entirely absent from the sacral vertebra (Zaharesco 1935, Kovalenko 1994, pers. obs.) In that case, the last presacral vertebra bears both sacral apophyses and postzygapophyses, which is similar to the condition in the vertebra from Sainte-Néboule. However, in such specimens the pathological nature of that arrangement is clearly apparent, most obviously with the apophyses having an irregular shape and/or being distorted. By contrast, the specimen from Sainte-Néboule exhibits no signs of pathology in its one preserved apophysis. That argues against the vertebra being from the pre-sacral series.

If the specimen from Sainte-Néboule is really a sacral vertebra and if its postzygapophysis is not the result of individual variation, then this sacral vertebra represents a peculiar, unknown taxon. However, assignment to the pelodytid referred to as cf. Pelodytes in the Phosphorites cannot be definitely rejected, because as noted above the specimen exhibits some pelodytid-like features.

\section{Discussion}

In their review of the anurans from the Tertiary of Europe, Rage and Roček (2003) listed six to eight families in the Eocene (Alytidae, Palaeobatrachidae, Pelobatidae, Pelodytidae, Ranidae, Leptodactylidae, and perhaps Microhylidae and Rhacophoridae) and four families in the Oligocene (Alytidae, Palaeobatrachidae, Pelobatidae, Ranidae). The Phosphorites mainly differ from the other European regions in lacking Palaeobatrachidae. This extinct family of aquatic frogs is relatively frequent in the European Eocene and Oligocene (Špinar 1972, Wuttke et al. 2012). In addition, Rage and Roček (2003) reported a leptodactylid frog from the late Eocene of France. As previously mentioned, this presumed leptodactylid (i.e., Thaumastosaurus, in the Phosphorites) has been transferred to the ranoids after scanning of one of the 'mummies' (Laloy et al. 2013); therefore, leptodactylids should be removed from the list of anurans of the Phosphorites (and most likely from the list of anurans from the Eocene of Europe). On the other hand, the presence of Pelodytidae in the Eocene of Europe is now confirmed on the basis of bones reported here from the Phosphorites.

The occurrence of a number of families in the Phosphorites has not yet been settled. Sanchiz (1998) reported the occurrence of Microhylidae and Rhacophoridae in the late Eocene of the Phosphorites (more precisely from Escamps, MP 19), but he did not describe the fossils and he did not indicate what skeletal elements were used for these identifications. Consequently, Rage and Roček (2003) did not regard the presence of these two families as confirmed. The available material does not help resolve this question. Bones that suggested the presence of microhylids (Sanchiz 1998) are most likely ilia that show a bufonid-like or microhylid-like morphology (see above). If they do not belong to bufonids, they might be ilia of microhylids, even though no other bones from the Phosphorites appear referable to the latter group. Alternatively, those bufonid- or microhylid-like ilia may represent an unknown taxon. The presence of rhacophorids (Sanchiz 1998) remains highly questionable, because no bone currently known from the Phosphorites may be confidently assigned to that family.

To sum up, the Eocene sequence of the Phosphorites has produced Alytidae (= Discoglossidae), Pelobatidae, Pelodytidae, and ranoids. The last group represents the most diverse assemblage in the Eocene of the Phosphorites; it includes at least two species of Thaumastosaurus and three indeterminate forms. In addition, although the presence of microhylids or bufonids, and rhacophorids appears to be quite unlikely, it is not possible to definitely reject any of those occurrences. The presence of an indeterminate taxon is possible on the basis of an odd sacrum.

The Oligocene sequence is less diverse, with only Alytidae, Pelobatidae and ranoids being definitely present in the Phosphorites.

The absence of Palaeobatrachidae from the Eocene and Oligocene of the Phosphorites most likely results from the local environment. They were obligate aquatic dwellers, which was likely not compatible with a karstic ecosystem. However, semi-aquatic or peri-aquatic frogs (sensu Böhme 2008), such as alytids of the Discoglossus group and probably some ranoids were able to live there.

The anuran fauna from the Oligocene of the Phosphorites is less rich and less diverse than that from the Eocene. This may be the consequence of several factors. First, a marked extinction event, the 'Grande Coupure', strongly affected the faunas at the Eocene-Oligocene boundary (Rage 1984a, 2012). In addition, cooling and aridification, which began during the Eocene, increased during the Oligocene.

Finally, it should be stressed that frog taxa identified at genus or species levels are rare in the Phosphorites. This results from the fact that with anuran remains being rare in each locality, it is difficult to determine the proper association of bones belonging to the same taxon and characterizing it.

\section{Acknowledgements}

I am most especially grateful to the members of the various crews that have worked the Phosphorites during the last five decades, to the staff of the Institut de l'Evolution, University of Montpellier, and to the 'Phosphatières du Quercy' association. I would like to thank Zbyněk Roček who invited me to contribute to this issue dedicated to Zdeněk V. Špinar. Thanks are also due to Salvador Bailon (MNHN) for access to comparative specimens. J.D. Gardner and $\mathrm{M}$. Venczel provided constructive reviews, which greatly improved this article. I thank also J. Wagner for editorial work and various comments. 


\section{References}

Agnolin, F. (2012): A new Calyptocephalellidae (Anura, Neobatrachia) from the Upper Cretaceous of Patagonia, Argentina, with comments on its systematic position. Studia Geologica Salmanticensia, 48: 129-178.

Astruc, J. G., Hugueney, M., Escarguel, G., Legendre, S., Rage, J.-C., Simon-Coinçon, R., Sudre, J., Sigé, B. (2003): Puycelci, nouveau site à vertébrés de la série molassique d'Aquitaine. Densité et continuité biochronologique dans la zone Quercy et bassins périphériques au Paléogène. - Geobios, 36: 629-648.

http://dx.doi.org/10.1016/j.geobios.2003.01.001

Báez, A. M., Gómez, R. (2014): Is hyperossification concealing the phylogenetic signal of osteological traits in anurans? A test-case from the upper Cretaceous of Brazil. - In: Maxwell, E., Miller-Camp, J. (eds), Program and Abstracts, $74^{\text {th }}$ Meeting of the Society of Vertebrate Paleontology, November $5^{\text {th }}-8^{\text {th }} 2014$, Berlin, Germany, p. 83.

Báez, A. M., Nicoli, L. (2004): Bufonid toads from the Late Oligocene beds of Salla, Bolivia. - Journal of Vertebrate Paleontology, 24: 73-79. http://dx.doi.org/10.1671/1900-6

Báez, A. M., Werner, C. (1996): Presencia de anuros Ranoideos en el Cretácico de Sudan [Presence of ranoid anurans in the Cretaceous of Sudan]. - Ameghiniana, 3: 460. (in Spanish)

Bailon, S. (1999): Différenciation ostéologique des anoures (Amphibia, Anura) de France. - In: Desse, J., DesseBerset, N. (eds), Fiches d'ostéologie animale pour l'archéologie, Série C: Varia, $\mathrm{n}^{\circ} 1$. Centre de recherches archéologiques du CNRS, Antibes, France, 41 pp.

Biton, R., Geffen, E., Vences, M., Cohen, O., Bailon, S., Rabinovich, R., Malka, Y., Oron, T., Boistel, R., Brumfeld, V., Gafny, S. (2013): The rediscovered Hula painted frog is a living fossil. - Nature Communications, 4: e1959. http://dx.doi.org/10.1038/ncomms2959

Blain, H. A., Delfino, M., Berto, C., Arzarello, M. (2016): First record of Pelobates syriacus (Anura, Amphibia) in the early Pleistocene of Italy. - In: Gardner, J. D., Přikryl, T. (eds), Contributions in honour of Zbyněk Roček. Palaeobiodiversity and Palaeoenvironments, 96: 111-124. http://dx.doi.org/10.1007/s12549-015-0220-1

Böhme, M. (2008): Ectothermic vertebrates (Teleostei, Allocaudata, Urodela, Anura, Testudines, Choristodera, Crocodylia, Squamata) from the Upper Oligocene of Oberleichtersbach (Northern Bavaria, Germany). Courier Forschungsinstitut Senckenberg, 206: 161-183.

Bonaparte, C. L. (1838): Iconographia della Fauna Italica per le Quattro Classi degli Animali Vertebrati. II. Amfibi. Fascicolo 23 [Pictorial Book of the Italian Fauna for the Four Classes of Vertebrate Animals. II. Amphibians. Vol. 23]. - Salviucci, Roma, (not paginated). (in Italian)

Bonaparte, C. L. (1850): Conspectus Systematum. Herpetologiae et Amphibiologiae. Editio altera reformata. E. J. Brill, Lugduni Batavorum [= Leiden], 1 p.

Chkhikvadze, V. M. (1985): Predvaritel'nye rezul'taty izucheniya tretichnykh amfibiy i cheshuychatykh reptiliy
Zaysanskoy Vpadiny [Preliminary results of the study of Tertiary amphibians and squamate reptiles of the Zaisan Basin]. - In: Voprosy Gerpetologii - Shestaya Vsesoyuznaya Gerpetologicheskaya Konferentsiya, Tashkent, 18-20 sentyabrya 1985, Avtoreferaty dokladov, p. 234-235. (in Russian)

Cope, E. D. (1865): Sketch of the primary groups of Batrachia Salientia. - Natural History Review, 1865: 97-120.

Crochet, J. Y. (1972): Les Vertébrés de l'Oligocène supérieur du Pech du Fraysse, poche à phosphate du Quercy (commune de Saint-Projet, Tarn-et-Garonne). - Compte rendu sommaire des séances de la Société géologique de France, 9: 316-317.

Crochet, J. Y., Hartenberger, J. L., Rage, J.-C., Rémy, J. A., Sigé, B., Sudre, J., Vianey-Liaud, M. (1981): Les nouvelles faunes de vertébrés antérieures à la "Grande Coupure" découvertes dans les phosphorites du Quercy. - Bulletin du Muséum national d'Histoire Naturelle de Paris, 4ème série, section C, 3: 245-266.

de Bonis, L., Crochet, J. Y., Rage, J.-C., Sigé, B., Sudre, J., Vianey-Liaud, M. (1973): Nouvelles faunes de vertébrés oligocènes des Phosphorites du Quercy. - Bulletin du Muséum national d'Histoire Naturelle, 3ème série, Sciences de la Terre, 28: 105-113.

de Broin, F., Buffetaut, E., Koeniger, J. C., Rage, J.-C., Russell, D., Taquet, P., Vergnaud-Grazzini, C., Wenz, S. (1974): La faune de vertébrés continentaux du gisement d'In Beceten (Sénonien du Niger). - Comptes rendus des séances de l'Académie des Sciences, série D, 279: 469-472.

de Stefano, G. (1903a): I Sauri del Quercy appartenenti alla collezione Rossignol [The saurians from the Quercy belonging to Rossignol's collection]. - Atti della Societá Italiana di Scienze naturali e del Museo Civico di Storia naturale in Milano, 42: 382-418. (in Italian)

de Stefano, G. (1903b): Sui Batraci Urodeli delle Fosforiti del Quercy [On the urodele batrachians from the Phosphorites du Quercy]. - Bollettino della Societá Geologica Italiana, 22: 40-50. (in Italian)

Duffaud, S. (2000): Les faunes d'amphibiens du Crétacé supérieur à l'Oligocène inférieur en Europe: paléobiodiversité, évolution, mise en place; PhD Thesis. - MS, Muséum national d'Histoire naturelle, Paris, France, 221 pp. (copy in author's private library).

Estes, R., Hecht, M., Hoffstetter, R. (1967): Paleocene amphibians from Cernay, France. - American Museum Novitates, 2295: 1-25.

Estes, R., Reig, O. A. (1973): The early fossil record of frogs. A review of the evidence. - In: Vial, J. L. (ed.), Evolutionary biology of the anurans, University of Missouri Press, Columbia, pp. 11-63.

Evans, S. E., Groenke, J. R., Jones, M. E. H., Turner, A. H., Krause, D. W. (2014): New material of Beelzebufo, a hyperossified frog (Amphibia: Anura) from the Late Cretaceous of Madagascar. - PLoS ONE, 9: e87236. http://dx.doi.org/10.1371/journal.pone.0087236

Evans, S. E., Jones, M. E. H., Krause, D. W. (2008): A giant frog with South American affinities from the Late Cretaceous of Madagascar. - Proceedings of the National Academy of Sciences, 105: 2951-2956. http://dx.doi.org/10.1073/pnas.0707599105 
Evans, S. E., Milner, A. R., Mussett, F. (1990): A discoglossid frog from the Middle Jurassic of England. - Palaeontology, 33: 299-311.

Filhol, H. (1873): Sur des pièces fossiles provenant de batraciens, de lacertiens et d'ophidiens, trouvées dans les dépôts de phosphate de chaux de l'Aveyron. - Comptes rendus de l'Académie des Sciences de Paris, 77: 1556-1557.

Filhol, H. (1876): Sur les Reptiles fossiles des phosphorites du Quercy. - Bulletin de la Société Philomatique de Paris, 11: 27-28.

Filhol, H. (1877): Recherches sur les phosphorites du Quercy. - Ed. Masson, Paris, 561 pp.

Fitzinger, L. J. (1843): Systema reptilium. Fasciculus primus. - Braumüller et Seidel, Vienna, 106 pp.

Folie, A., Rana, R. S., Rose, K. D., Sahni, A., Kumar, K., Singh, L., Smith, T. (2013): Early Eocene frogs from Vastan Lignite Mine, Gujarat, India. - Acta Palaeontologica Polonica, 3: 511-524.

Friant, M. (1944): Caractères anatomiques d'un batracien oligocène de la Limagne, le Prodiscoglossus Vertaizoni nov. gen. nov. spec. - Comptes-Rendus hebdomadaires des séances de l'Académie des Sciences, 219: 561-562.

Frost, D. R., Grant, T., Faivovich, J., Bain, R. H., Haas, A., Haddad, C. F. B., de Sá, R. O., Channing, A., Wilkinson, M., Donnellan, S. C., Raxworthy, C. J., Campbell, J. A., Blotto, B., Moler, P., Drewes, R. C., Nussbaum, R. A., Lynch, J. D., Green, D. M., Wheeler, W. C. (2006): The amphibian tree of life. - Bulletin of the American Museum of Natural History, 297: 1-370.

http://dx.doi.org/10.1206/0003-0090(2006)297[0001:TA TOL]2.0.CO;2

Gardner, J. D., DeMar, D. G. Jr. (2013): Mesozoic and Palaeocene lissamphibian assemblages of North America: a comprehensive review. - In: Gardner, J. D., Nydam, R. L. (eds), Mesozoic and Cenozoic lissamphibian and squamate assemblages of Laurasia. Palaeobiodiversity and Palaeoenvironments, 93: 459-515.

http://dx.doi.org/10.1007/s12549-013-0130-z

Garsault, F. A. P. de (1764): Les Figures des plantes et animaux d'usage en médecine, décrits dans la Matière Médicale de Mr. Geoffroy Médecin. - Desprez, Paris, v + 20 pp., pl. 644-729.

Gaudant, J. (1993): Nouvelles recherches sur l'ichthyofaune oligo-miocène du Puy de Mur (Puy-de-Dôme). - Géologie de la France, 4: 25-37.

Gelfo, J. N., Goin, F. J., Woodburne, M. O., Muizon, C. de (2009): Biochronological relationships of the earliest South American Paleogene mammalian faunas. Palaeontology, 52: 251-269. http://dx.doi.org/10.1111/j.1475-4983.2008.00835.x

Gómez, R. O., Turazzini, G. F. (2016): An overview of the ilium of anurans (Lissamphibia, Salientia), with a critical appraisal of the terminology and primary homology of main ilial features. - Journal of Vertebrate Paleontology, 36(1): e1030023.

http://dx.doi.org/10.1080/02724634.2015.1030023

Gray, J. E. (1825): A synopsis of the genera of Reptiles and Amphibia, with a description of some new species. Annals of Philosophy, Series 2, 10: 193-217.
Guayasamin, J. M., Castroviejo-Fischer, S., Trueb, L., Ayarzagüena, J., Rada, M., Vilà, C. (2009): Phylogenetic systematics of glassfrogs (Amphibia: Centrolenidae) and their sister taxon Allophryne ruthveni. - Zootaxa, 2100: $1-97$.

Günther, A. C. L. G. (1858): On the systematic arrangement of the tailless batrachians and the structure of Rhinophrynus dorsalis. - Proceedings of the Zoological Society of London, 1858: 339-352. http://dx.doi.org/10.1111/j.1469-7998.1858.tb06387.x

Henrici, A. C. (1994): Tephrodytes brassicarvalis, new genus and species (Anura: Pelodytidae), from the Arikareean cabbage patch beds of Montana, USA, and PelodytidPelobatid relationships. - Annals of Carnegie Museum, 63: 155-183.

Henrici, A. C., Báez, A. M., Grande, L. (2013): Aerugoamnis paulus, new genus and new species (Anura: Anomocoela): first reported anuran from the early Eocene (Wasatchian) Fossil Butte Member of the Green River Formation, Wyoming. - Annals of Carnegie Museum, 81: 295-309. http://dx.doi.org/10.2992/007.081.0402

Hoffstetter, R. (1945): A propos de deux fossiles des Phosphorites du Quercy: Enigmatosaurus Bottii (G. de Stefano 1903) et Amphignathodon sp. J. Piveteau 1927. - Bulletin de la Société géologique de France, 15:167-169.

Holman, J. A., Harrison, D. L. (2002): A new Thaumastosaurus (Anura: Familia Incertae Sedis) from the Late Eocene of England, with remarks on the taxonomic and zoogeographic relationships of the genus. - Journal of Herpetology, 36: 621-626.

http://dx.doi.org/10.1670/0022-1511(2002)036[0621:AN TAFI]2.0.CO;2

Holman, J. A., Harrison, D. L. (2003): A new helmeted frog of the genus Thaumastosaurus from the Eocene of England. - Acta Palaeontologica Polonica, 48: 157-160.

Kovalenko, E. E. (1994): The compound sacrum in individual variability of common platanna (Xenopus laevis). - Russian Journal of Herpetology, 1: 172-178.

Kovalenko, E. E., Kruzhkova, Yu. I. (2013): Individual variation in the development of the common toad, Bufo bufo (Anura, Bufonidae): 2. Diagnostic characters of the axial skeleton. - Russian Journal of Developmental Biology, 44: 180-193. http://dx.doi.org/10.1134/S1062360413040048

Laloy, F., Rage, J.-C., Evans, S. E., Boistel, R., Lenoir, N., Laurin, M. (2013): A re-interpretation of the Eocene anuran Thaumastosaurus based on microCT examination of a 'mummified' specimen. - PLoS ONE, 8: e74874. http://dx.doi.org/10.1371/journal.pone.0074874

Lataste, F. (1879): Etude sur le Discoglossus pictus Otth. Actes de la Société Linnéenne de Bordeaux, 3: 275-342.

Legendre, S., Sigé, B., Astruc, J. G., de Bonis, L., Crochet, J. Y., Denys, C., Godinot, M., Hartenberger, J. L., Lévêque, F., Marandat, B., Mourer-Chauviré, C., Rage, J.-C., Rémy, J. A., Sudre, J., Vianey-Liaud, M. (1997): Les phosphorites du Quercy: 30 ans de recherche. Bilan et perspective. - Geobios, mémoire special, 20: 331-345. http://dx.doi.org/10.1016/S0016-6995(97)80038-1

Lehr, E., Trueb, L. (2007): Diversity among New World microhylid frogs (Anura: Microhylidae): morphological 
and osteological comparisons between Nelsonophryne (Günther 1901) and a new genus from Peru. - Zoological Journal of the Linnean Society, 149: 583-609. http://dx.doi.org/10.1111/j.1096-3642.2007.00270.x

Linnaeus, C. (1758): Systema Naturae per Regna Tria Naturae, Secundum Classes, Ordines, Genera, Species, cum Characteribus, Differentiis, Synonymis, Locis. 10th Edition. Volume 1. - Laurentii Salvii, Holmiae, 824 pp.

MacPhee, R. D., Burney, D. A., Wells, N. A. (1985): Early Holocene chronology and environment of Ampasambazimba, a Malagasy subfossil lemur site. - International Journal of Primatology, 6: 463-489. http://dx.doi.org/10.1007/BF02735571

Maridet, O., Costeur, L., Legendre, S. (2013): European Neogene rodent communities: explaining family-level replacements through a spatiotemporal approach. Historical Biology, 25: 655-677. http://dx.doi.org/10.1080/08912963.2012.739170

Martín, C., Alonso-Zarazaga, M. A., Sanchiz, B. (2012): Nomenclatural notes on living and fossil amphibians. Graellsia, 68: 159-180. http://dx.doi.org/10.3989/graellsia.2012.v68.056

Milner, A. C. (1986): Amphibians and squamates from the Palaeogene of England. - In: Roček, Z. (ed.), Studies in Herpetology, Charles University, Prague, pp. 685-688.

Nokariya, H. (1983): Comparative osteology of Japanese frogs and toads for paleontological studies (I): Bufo, Hyla, Microhyla and Bombina. - Bulletin of the National Science Museum Tokyo, 9: 23-40.

Nopcsa, F. (1908): Zur Kenntnis der fossilen Eidechsen. Beiträge zur Paläontologie und Geologie ÖsterreichUngarns und des Orients, 21: 34-62.

Oken, L. (1816): Lehrbuch der Naturgeschichte. Theil 3. Zoologie. Abtheilung 2. - C. H. Reclam, Leipzig, 1270 pp.

Oliveira, E. V., Goin, F. J. (2011): A reassessment of bunodont metatherians from the Paleogene of Itaboraí (Brazil): Systematics and the age of the Itaboraian SALMA. - Revista Brasileira de Paleontologia, 14: 105-136. http://dx.doi.org/10.4072/rbp.2011.2.01

Otth, A. (1837): Beschreibung einer neuen europäischen Froschgattung, Discoglossus. - Neue Denkschriften der Allgemeinen Schweizerischen Gesellschaft für die Gesammten Naturwissenschaften, 1: 1-8.

Parker, H. W. (1929): Two fossil frogs from the Lower Miocene of Europe. - Annals and Magazine of Natural History, 270-281. http://dx.doi.org/10.1080/00222932908673051

Pélissié, T., Sigé, B. (eds) (2006): 30 millions d'années de biodiversité dynamique dans le paléokarst du Quercy. Strata, 13: 3-284.

Piveteau, J. (1927): Etudes sur quelques amphibiens et reptiles fossiles. 1ère partie. - Annales de Paléontologie, 16: 61-97.

Rafinesque, C. S. (1814): Fine del prodromo d'erpetologia siciliana [Final part of the study on Sicilian herpetology]. - Specchio delle Scienze, o, Giornale Enciclopedico di Sicilia, 2: 102-104. (in Italian)

Rage, J.-C. (1981): Les continents péri-atlantiques au Crétacé supérieur: migrations des faunes continentales et problèmes paléogéographiques. - Cretaceous Research, 2: 65-84. http://dx.doi.org/10.1016/S0195-6671(81)80005-5
Rage, J.-C. (1984a): La "grande coupure" éocène/oligocène et les herpétofaunes (Amphibiens et Reptiles): problème du synchronisme des événements paléobiogéographiques. - Bulletin de la Société géologique de France, 26: 1251-1257. http://dx.doi.org/10.2113/gssgfbull.S7-XXVI.6.1251

Rage, J.-C. (1984b): Are the Ranidae (Anura, Amphibia) known prior to the Oligocene? - Amphibia-Reptilia, 5: 281-288.

Rage, J.-C. (1988): Le gisement du Bretou (Phosphorites du Quercy, Tarn-et-Garonne, France) et sa faune de vertébrés de l'Eocène supérieur. I. Amphibiens et Reptiles. Palaeontographica, A, 205: 3-27.

Rage, J.-C. (2003): Oldest Bufonidae (Amphibia, Anura) from the Old World: a bufonid from the Paleocene of France. - Journal of Vertebrate Paleontology, 23: 462-463.

http://dx.doi.org/10.1671/0272-4634(2003)023[0462:OB AAFT]2.0.CO;2

Rage, J.-C. (2006): The lower vertebrates from the Eocene and Oligocene of the phosphorites du Quercy (France): an overview. - In: Pélissié, T., Sigé, B. (eds), 30 millions d'années de biodiversité dynamique dans le paléokarst du Quercy. Strata, 13: 161-173.

Rage, J.-C. (2012): Amphibians and squamates in the Eocene of Europe: what do they tell us? - In: Lehmann, T., Schaal, S. F. K. (eds), Messel and the terrestrial Eocene Proceedings of the $22^{\text {nd }}$ Senckenberg Conference. Palaeobiodiversity and Palaeoenvironments, 92: 445-457. http://dx.doi.org/10.1007/s12549-012-0087-3

Rage, J.-C., Augé, M. (2015): Valbro: A new site of vertebrates from the early Oligocene (MP22) of France (Quercy). III - Amphibians and squamates. - Annales de Paléontologie, 101: 29-24.

http://dx.doi.org/10.1016/j.annpal.2014.10.002

Rage, J.-C., Ford, R. L. E. (1980): Amphibians and Squamates from the Upper Eocene of the Isle of Wight. - Tertiary Research, 3: 47-60.

Rage, J.-C., Hossini, S. (2000): Les Amphibiens du Miocène moyen de Sansan. - In: Ginsburg, L. (ed.), La faune miocène de Sansan et son environnement. Mémoires du Muséum national d'Histoire naturelle, 183: 177-217.

Rage, J.-C., Roček, Z. (2003): Evolution of anuran assemblages in the Tertiary and Quaternary of Europe, in the context of palaeoclimate and palaeogeography. Amphibia-Reptilia, 24: 133-167. http://dx.doi.org/10.1163/156853803322390408

Rage, J.-C., Roček, Z. (2007): A new species of Thaumastosaurus (Amphibia: Anura) from the Eocene of Europe. - Journal of Vertebrate Paleontology, 27: 329-336. http://dx.doi.org/10.1671/0272-4634(2007)27[329:ANS OTA]2.0.CO;2

Rage, J.-C., Vergnaud-Grazzini, C. (1978): La poche à phosphate de Ste-Néboule (Lot) et sa faune de Vertébrés du Ludien supérieur. 2. Amphibiens. Etude préliminaire. - Palaeovertebrata, 8: 175-179.

Roček, Z. (1994): Taxonomy and distribution of Tertiary discoglossids (Anura) of the genus Latonia v. Meyer, 1843. - Geobios, 27: 717-751. http://dx.doi.org/10.1016/S0016-6995(94)80058-8 
Roček, Z., Eaton, J. G., Gardner, J. D., Přikryl, T. (2010): Evolution of anuran assemblages in the Late Cretaceous of Utah, USA. - Palaeobiodiversity and Palaeoenvironments, 90: 341-393. http://dx.doi.org/10.1007/s12549-010-0040-2

Roček, Z., Gardner, J. D., Eaton, J. G., Přikryl, T. (2013): Anuran ilia from the Upper Cretaceous of Utah Diversity and stratigraphic patterns. - In: Titus, A. L., Loewen, M. A. (eds), At the top of the grand staircase: the Late Cretaceous of southern Utah, Indiana University Press, Bloomington, pp. 273-294.

Roček, Z., Lamaud, P. (1995): Thaumastosaurus bottii de Stefano, 1903, an anuran with Gondwanan affinities from the Eocene of Europe. - Journal of Vertebrate Paleontology, 15: 506-515. http://dx.doi.org/10.1080/02724634.1995.10011244

Roček, Z., Rage, J.-C. (2000): Tertiary Anura of Europe, Africa, Asia, and North America. - In: Heatwole, H., Carroll, R. L. (eds), Amphibian Biology, 4: Palaeontology, Surrey Beatty and sons, Chipping Norton, pp. 1332-1387.

Roček, Z., Wuttke, M., Gardner, J. D., Bhullar. B.-A. S. (2014): The Euro-American genus Eopelobates, and a re-definition of the family Pelobatidae (Amphibia, Anura). - Palaeobiodiversity and Palaeoenvironments, 94: 529-567. http://dx.doi.org/10.1007/s12549-014-0169-5

Sanchiz, B. (1978): Nuevos restos fósiles de la familia Pelodytidae (Amphibia, Anura) [New fossil remains of the family Pelodytidae (Amphibia, Anura)]. - Estudios Geologicos, 34: 9-27. (in Spanish)

Sanchiz, B. (1998): Salientia. Handbuch der Paläoherpetologie, Part 4. - Verlag Dr. Friedrich Pfeil, München, 275 pp.

Sanchiz, B., Tejedo, M., Sánchez-Herráiz, M. J. (2002): Osteological differentiation among Iberian Pelodytes (Anura, Pelodytidae). - Graellsia, 58: 35-68. http://dx.doi.org/10.3989/graellsia.2002.v58.i2.277

Schmidt-Kittler, N. (1987): Correlation table. - In: SchmidtKittler, N. (ed.), International Symposium on Mammalian biostratigraphy and paleoecology of the European Paleogene. Münchner Geowissenschaftliche Abhandlungen, A, 10: 17.

Seeley, H. G. (1874): Note on some of the generic modifications of the plesiosaurian pectoral arch. Quarterly Journal of the Geological Society of London, 30: 436-449. http://dx.doi.org/10.1144/GSL.JGS.1874.030.01-04.48

Sigé, B., Aguilar, J. P., Marandat, B., Astruc, J. G. (1991): Extension au Miocène inférieur des remplissages phosphatés du Quercy. La faune de vertébrés de Crémat (Lot, France). - Geobios, 24: 497-502. http://dx.doi.org/10.1016/S0016-6995(06)80251-2

Szentesi, Z., Venczel, M. (2012): A new discoglossid frog from the Upper Cretaceous (Santonian) of Hungary. Cretaceous Research, 34: 327-333. http://dx.doi.org/10.1016/j.cretres.2011.11.012

Špinar, Z. V. (1952): Eopelobates bayeri - nová žába z českých třetihor [Eopelobates bayeri - a New Frog from the Tertiary of Bohemia]. - Sborník Ústředního ústavu geologického, 19: 457-488. (in Czech)
Špinar, Z. V. (1972): Tertiary frogs from Central Europe. Academia, Prague and W. Junk N.V., The Hague, 346 pp. http://dx.doi.org/10.1007/978-94-010-2932-2

Taylor, E. H. (1941): A new anuran from the middle Miocene of Nevada. - University of Kansas Science Bulletin, 27: 61-69.

Taylor, E. H., Noble, G. K. (1924): A new genus of discoglossid frogs from the Philippine Islands. American Museum Novitates, 121: 1-4.

Trueb, L. (1973): Bones, frogs, and evolution. - In: Vial, J. L. (ed.), Evolutionary biology of the anurans, University of Missouri Press, Columbia, pp. 65-132.

Tyler, M. J. (1994): Hylid frogs from the mid-Miocene Camfield beds of Northern Australia. - Beagle, Records of the Museums and Art Galleries of the Northern Territory, 11: 141-144.

Venczel, M., Hír, J. (2013): Amphibians and squamates from the Miocene of Felsötárkány Basin, N-Hungary. Palaeontographica, A, 300: 117-158.

http://dx.doi.org/10.1127/pala/300/2013/117

von Meyer, H. (1841): Thaumatosaurus oolithicus, der fossile Wonder-Saurus aus dem Oolith. - Neues Jahrbuch für Mineralogie, Geognosie, Geologie und Petrefactenkunde, 1841: 176-184.

von Meyer, H. (1843): Summarische Uebersicht des fossilen Wirbelthiere des Mainzer Tertiär-Beckens, mit besonderer Rücksicht auf Weisenau. - Neues Jahrbuch für Mineralogie, Geognosie, Geologie und Petrefactenkunde, 1843: 379-410.

Wagler, J. (1830): Natürliches System der Amphibien, mit vorangehender Classification der Säugthiere und Vogel. Ein Beitrag zur vergleichenden Zoologie. - J. G. Cotta, München, Stuttgart and Tübingen, 354 pp.

Weitzel, K. (1938): Propelodytes wagneri n.g. n.sp., ein Frosch aus dem Mitteleozän von Messel. - Notizblatt der Hessischen Geologischen Landesanstalt zu Darmstadt, 19: 42-46.

Wettsttein-Westersheimb, O. (1955): Die Fauna der miozänen Spaltenfüllung von Neudorf a.d. March (ČSR). Amphibia (Anura) et Reptilia. - Sitzungsberichte der Österreichischen Akademie der Wissenschaften, Mathematisch-Naturwissenschaftliche Klasse, 164: 801-815.

Wuttke, M. (2012): The genus Eopelobates (Anura, Pelobatidae) from Messel, Geiseltal, and Eckfeld (Middle Eocene, Germany). Part I: Redescription of Eopelobates wagneri (Weitzel, 1938) from Messel (Lower Geiseltalium, Germany). - Kaupia, 18: 43-71.

Wuttke, M., Přikryl, T., Ratnikov, V. Yu., Dvořák, Z., Roček, Z. (2012): Generic diversity and distributional dynamics of the Palaeobatrachidae (Amphibia: Anura). - Palaeobiodiversity and Palaeoenvironments, 92: 367-395. http://dx.doi.org/10.1007/s12549-012-0071-y

Zaharesco, V. (1935): Recherches anatomiques et morphogéniques sur les variations numériques de la colonne vertébrale chez la grenouille (Rana esculenta L.). Annales scientifiques de l'Université de Jassy, 20: 370-406. 